\title{
Immunohistochemical detection of Tritrichomonas foetus in experimentally infected mice $^{1}$
}

\author{
Cristina Esther Monteavaro ${ }^{2}$, Pedro Soto ${ }^{2}$, Hilda María Echevarría ${ }^{2}$, María del \\ Carmen Catena ${ }^{2}$, Enrique Leo Portiansky ${ }^{3}$ and Eduardo Juan Gimeno ${ }^{3 *}$
}

\begin{abstract}
Monteavaro, C.E., Soto P., Echevarría H.M., Catena M.C., Portiansky E.L. \& Gimeno E.J. 2000. Immunohistochemical detection of Tritrichomonas foetus in experimentally infected mice. Pesquisa Veterinária Brasileira 20(1):43-46. Institute of Pathology, Veterinary School, UNLP, P.O.Box 296, 1900 La Plata, Argentina.

The need to intensify knowledge of the pathogenesis of bovine genital trichomoniasis (BGT) led to the use of alternative animal models such as the mouse. Nevertheless, it is necessary to elucidate the dynamics of the infection in this animal species, evaluating different stages of the colonization and evolution of the pathological alterations. The immunohistochemistry (IHC) offers advantages over the routine histopathological staining techniques for the detection of the protozoan in tissues, cellular detritus and inside the macrophages. The goal of the present study was to demonstrate the presence of Tritrichomonas foetus in the reproductive tract of infected mice using an IHC technique. Female BALB/c mice were infected with a suspension of $T$. foetus by intravaginal route, in the estrum phase, detected by exfoliative vaginal cytology. After 10 weeks, the animals were sacrificed; uterus and vagina were fixed and histologically processed. Some slides were stained with HE. The rest of the slides were processed for IHC. An immunoadsorbed polyclonal serum against T. foetus was used. The avidine-biotine technique (HistoMouse, Zymed ${ }^{\mathrm{TM}}$ ) was employed. The histopathological studies showed a dilation of the uterine glands, presence of macrophages in the lumen of the organ and inner part of the endometrial glands. No T. foetus was identified using this method. The IHQ allowed additionally the identification of the protozoan in the endometrium, endometrial glands, uterine lumen and inside neutrophils and macrophages. The cytological studies stained with IHC showed either isolated T. foetus adhered to epithelial cells or inside macrophages. This technique proves to be a useful tool for the study of the pathogenesis of bovine genital trichomoniasis (BGT) in an experimental model.
\end{abstract}

INDEX TERMS: Tritrichomonas foetus, bovine genital trichomoniasis, immunohistochemistry, mouse.

RESUMO.- [Deteç̧ão imunohistoquímica de Tritrichomonas foetus em camundongos experimentalmente infectados.] A necessidade de aumentar o conhecimento da patogenia da tricomoníase genital bovina (BGT) conduziu ao uso de modelos experimentais alternativos como o camundongo. Não obstante, é necessário elucidar a dinâmica da infecção nesta

\footnotetext{
${ }^{1}$ Accepted for publicatin on January 3, 2000.

${ }^{2}$ Laboratory of Clinical and Experimental Microbiology, Veterinary School, UNICEN, Tandil, Argentina.

${ }^{3}$ Institute of Pathology, Veterinary School, UNLP, P.O. Box 296, 1900 La Plata, Argentina. "Author to whom correspondence should be addressed: Dr. Eduardo Juan Gimeno, ejgimeno@fcv.medvet.unlp.edu.ar, Institute of Pathology, School of Veterinary Sciences, UNLP, Calle 60 y 118, 1900 La Plata, Argentina; Tel. 54-221-483 6880 ext. 426, Fax 54-221-425 3276 / 7980.
}

espécie e avaliar as diferentes fases da colonização e evolução das alterações patológicas. A imunohistoquí-mica (IHQ) oferece vantagens sobre as técnicas histoquímicas de rotina para a observação do protozoário em tecidos, detritos celulares e dentro de macrófagos. $O$ objetivo do presente trabalho foi demonstrar pelo uso de uma técnica de IHQ a presença de Tritrichomonas foetus no sistema reprodutivo de camundongos infectados. Camundongos BALB/c fêmeas foram infectados pela via intravaginal, com uma suspensão de $T$. foetus, na fase de estro, detectado com citologia exfoliativa vaginal. Depois de 10 semanas, os animais foram sacrificados; útero e vagina forma fixados e processados para histologia. Alguns cortes foram corados com HE. O restante dos cortes foi processado para IHQ. Foi usado um soro policlonal imunoadsorvido anti-T. foetus. A técnica de avidina- 
biotina (HistoMouse, Zymed $^{\mathrm{TM}}$ ) foi empregada. Os estudos histopatológicos mostraram uma dilatação das glândulas uterinas, presença de macrófagos no lúmen do órgão e parte interna das glândulas endometriais. T. foetus não foi identificado por esse método. A IHQ permitiu identificar as mesmas lesões observadas e a presença do protozoário no endométrio, nas glândulas endometriais, no lúmen uterino e dentro de neutrófilos e macrófagos. $O$ estudo citológico em lâminas coradas por IHQ, mostrou T. foetus aderido a células epiteliais, ou dentro de macrófagos. Esta técnica demonstra ser uma ferramenta útil para o estudo da patogenia da tricomoníase genital bovina (BGT) utilizando-se o camundongo como modelo experimental.

TERMOS DE INDEXAÇÃO: Tritrichomonas foetus, tricomoníase genital bovina, imunohistoquímica, camundongo.

\section{INTRODUCTION}

The bovine genital trichomoniasis (BGT) is a venereal illness that naturally affects cattle, the causal agent of which is the protozoan Tritrichomonas foetus. From the studies of dynamics of the intravaginal infection carried out on laboratory animals, the mouse turns out to be the animal of election (St Claire et al. 1994, Hook et al. 1995, Mutwiri \& Corbeil 1998, Kulda et al. 1999). The BALB/c strain was the one that better responded to the infection, manifesting a bigger persistence (Van Andel et al. 1996). This strain was also used to determine the degree of pathogenicity of the protozoan (Soto et al. 1997).

In the experimental infection of estrogenized mice with T. foetus the histopathological slides stained with haematoxylin-eosin (HE) allowed to diagnose a moderate dilation of the uterus, glandular atrophy, abscesses of uterine glands, pyometra, lymphoid perivascular intramural infiltrate and ovaric bursitis (Van Andel et al. 1996). The described lesions in these mice were similar to those described by Parsonson et al. (1976) in bovine natural infection, suggesting that the mouse could be a model for the study of the bovine genital trichomoniasis.

Considering the genital trichomoniasis as a disease that affects the mucosa of the genital apparatus, the analysis of the immunopathogenesis still has a great interest, given the need to elucidate the molecular aspects of the agent-host interrelation. These studies would contribute to a better understanding of the illness with diagnostic goals and control. The mouse model offers advantages over the bovine model since it allows to control the environment variables with low cost and to carry out a meticulous study of the different phases of the pathogenesis.

Diverse immunohistochemical (IHC) techniques have already been used to demonstrate the presence of $T$. foetus in the infected animal. Burguess \& Knoblock (1989) used a monoclonal antibody against Tritrichomonas in immunofluorescence tests. Campero et al. (1989) used the peroxidaseantiperoxidase (PAP) technique with the aim of visualizing the protozoan in formaldehyde-fixed paraffin-embedded tissues. Rhyan et al. (1995a) used a labeled streptavidine-biotin immunohistochemical method employing a monoclonal antibody to determine the presence and the invasive power of T. foetus in bovine placental and fetal tissues. These authors showed the advantages of this technique in comparison with histopathology since it allows to detect the agent even in necrotic material and inside macrophages (Rhyan et al. 1995a, Rhyan et al. 1995b).

The goal of the present work was to demonstrate the presence of T. foetus or its antigens in the infected reproductive apparatus of female mice comparing two techniques for observation of the protozoan: staining with $\mathrm{HE}$ and an avidinebiotine commercial technique. The obtained results would be used for studies on the pathogenesis of the disease.

\section{MATERIALS AND METHODS}

\section{Animals}

Forty female BALB/c 6-8 weeks old mice were used, weighing approximately $20 \mathrm{~g}$, maintained with $12 \mathrm{hs}$ light per day, at constant temperature of $24^{\circ} \mathrm{C}$, and with food and water ad libitum. From the total, 10 mice in estrous as determined by vaginal exfoliative cytology were selected as experimental group. Five mice were selected from the remaining animals to be used as negative controls.

\section{Vaginal exfoliative cytology}

Vaginal washes with $10 \mathrm{ml}$ sterile PBS (Phosphate buffered saline) were performed in all the mice. Cell smears were observed with an optic microscope at a magnification of 1000x. The ovarian cell cycle was thus determined as well as the presence of the protozoan (Allen 1922).

\section{Experimental infection}

T. foetus var. Belfast isolated from bovine prepucial washes (Soto \& Parma 1989) was used. The sample was seeded in Diamond media (Diamond 1987). The protozoa were washed three times with PBS pH 7.2 by centrifugation of the sample for $10 \mathrm{~min}$. at $2500 \mathrm{Xg}$. Mice from the experimental group were inoculated with $10 \mathrm{ml}$ containing a suspension of $9 \times 10^{7} \mathrm{~T}$. foetus $/ \mathrm{ml}$, by intravaginal route. All the animals were followed up weekly by means of vaginal exfoliative cytology.

\section{Sampling}

Animals were sacrificed by cervical dislocation. Samples of vagina and uterus (body and horns) were fixed in Bouin's solution. The samples were embedded in paraffin and cut at $5 \mathrm{~mm}$. Some slides were stained with HE for histopathological diagnosis.

\section{Immunohistochemistry}

An immunoadsorbed polyclonal serum against Tritrichomonas was used as the specific antibody. It was obtained from a hyperimmunized rabbit policlonal serum and immunoadsorbed with whole T. foetus. The work dilution estimated by DOT-BLOT (Sanz \& Parma 1992), was 1:500. The slides were deparaffinized with alcohol of increasing graduation. An antigen retrieval process using a pressure cooker (Portiansky et al. 1997) was applied before overnight incubation with the primary antibody. The amplification system used was an avidinebiotine-peroxidase-based kit (HistoMouse, Zymed ${ }^{\mathrm{TM}}$ ), and its substrate was AEC (3-amino 9-ethyl carbazol). Normal rabbit serum and PBS were used as negative controls of the immunohistochemical reaction. Sections of infected animals were also processed. 


\section{RESULTS}

The vaginal exfoliative cytology of the infected animals revealed the presence of $T$. foetus. The HE staining allowed the diagnosis of dilation of the uterine glands and the presence of macrophages in the lumen of the organ, as well as inside the endometrial glands. The identification of the protozoan in this material was difficult. However, the IHC staining revealed the presence of $T$. foetus adhered to the epithelium and to desquamated cells, as well as inside macrophages (Fig. 1A). A detail of the previous figure can be seen in Fig. 2. The IHC control showed no staining (Fig. 1B). This technique allowed the identification of the protozoan in the endometrium and endometrial uterine glands. Polymorphonuclear leukocytes and macrophages engulfing T. foetus were observed in the uterine lumen and inner part of the endometrial glands (Fig. 3). Protozoan antigens were also observed in the endometrial cells. No T. foetus was observed in the vaginal slides. Nevertheless a strong positive reaction was found at the surface of the vaginal epithelium. No IHC reaction was observed in non-infected animals.

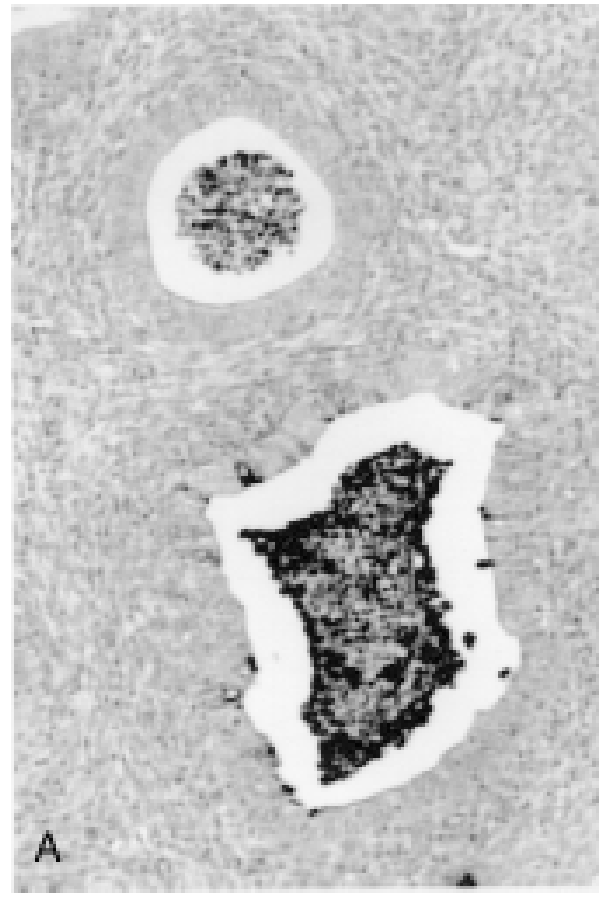

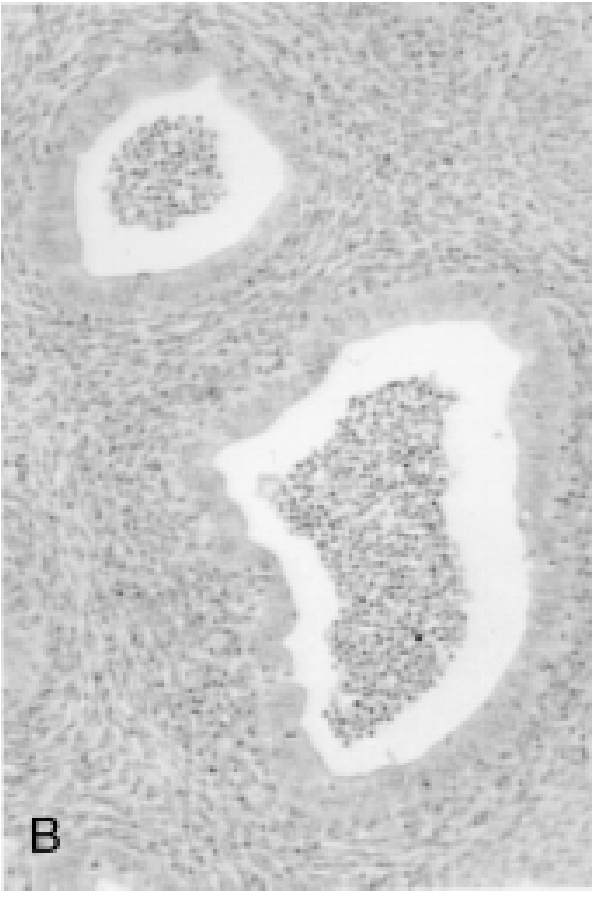

Fig. 1. Endometrial glands showing cellular desquamation and exudate. (A) Tritrichomonas foetus adhered to the epithelial cells, and free or inside the exudate. (B) Control negative-IHC sections. 100x.

Fig. 2. A detail of Fig. 1A showing Tritrichomonas foetus adhered to the epithelial cells, and free or inside the exudate. 400x.

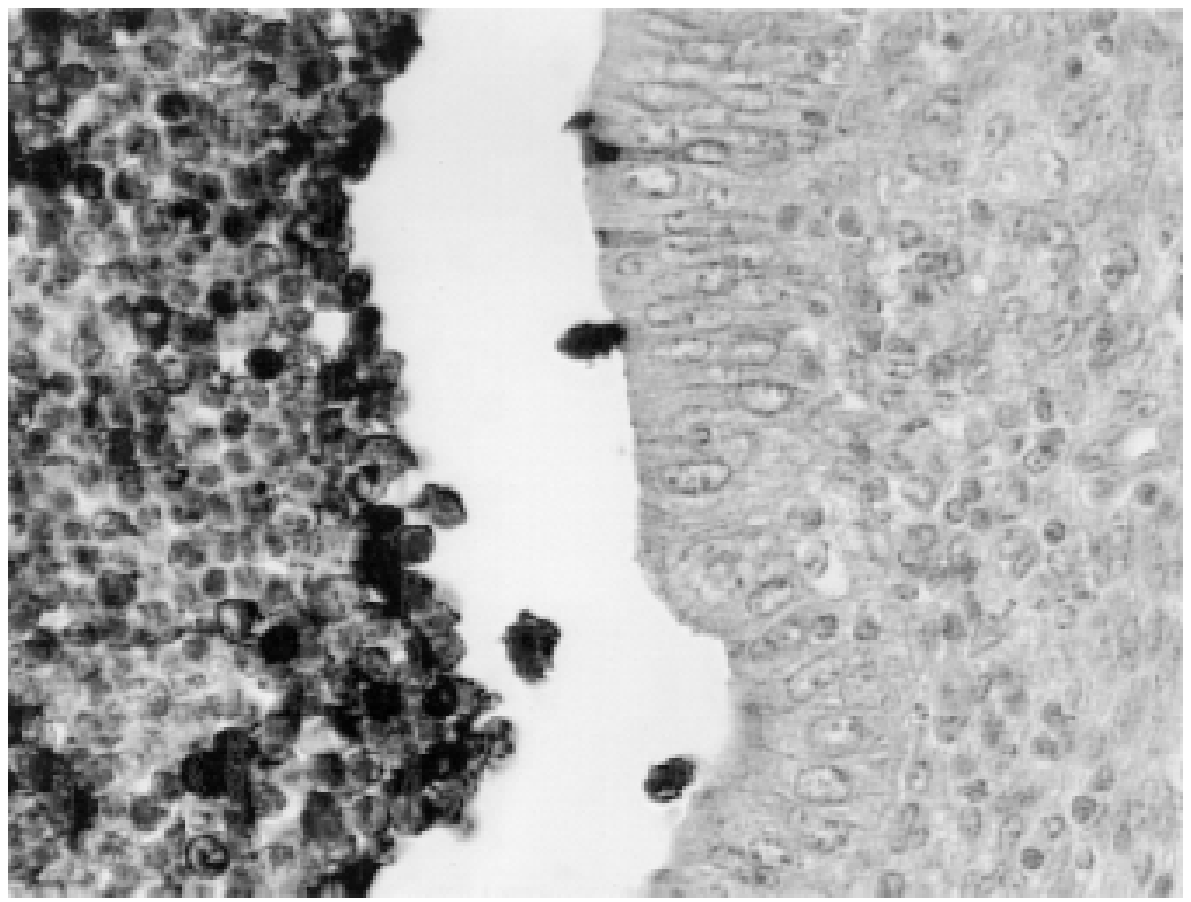


Fig. 3. Free (A) or macrophage engulfed (B) Tritrichomonas foetus in the lumen of the glands. 1000x.
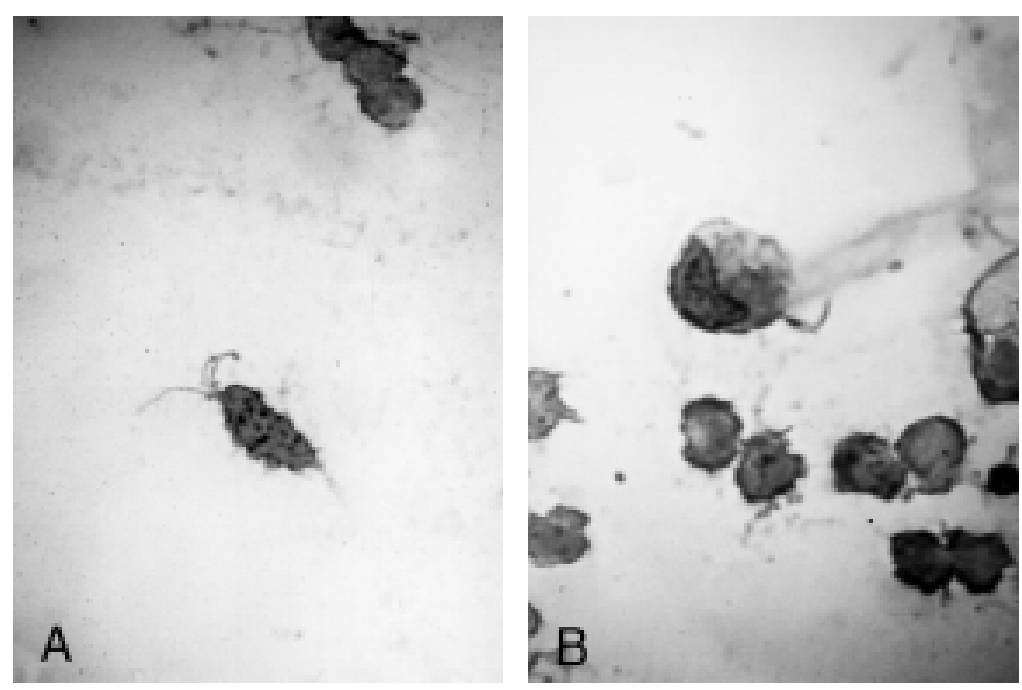

\section{DISCUSSION}

The IHC method used has shown to be effective for the in situ immunostaining of $T$. foetus in our experimental mice model. These results agree to those observed by Rhyan et al. (1995a) in placental and fetal tissues obtained from natural bovine infections.

The observed lesions were partially coincident with those described by Van Andel et al. (1996) in estrogenized mice. Although T. foetus could be observed when conventional stains were applied to the infected tissues (Parsonson et al. 1976, Rhyan et al. 1995b), the immunodetection happened to be more advantageous since it facilitated the individualization of the protozoan in exudates, necrotic material and inside macrophages. In those cases in which the protozoan penetrated the mucosa, its identification with HE was extremely difficult, while it was clearly detected with IHC techniques.

The used immunoadsorbed polyclonal serum allowed to identify the entire protozoan structures, including the undulant membrane and flagellum that had not been recognized by the monoclonal antibody used by Rhyan (1995b). These differences would permit the simultaneous recognition of numerous epitopes when a policlonal antibody was used. The presence of isolated, strongly positive cells in the endometrial epithelium could be an indication for the uptake of protozoal antigens. Those cells could be similar to the interdigitant cells that play a central role in local immunity.

The experimental model in mice and the IHC demonstration of antigenic fractions of $T$. foetus could be a useful tool for the study of the immunopathogenesis of bovine genital trichomoniasis.

Acknowledgements.- The authors would like to thank Mrs. Rosa Villegas for their technical assistance. Financial support was provided in part by grants from the Consejo Nacional de Investigaciones Científicas (CONICET), Argentina. The language correction of Dr. Sheryl Macnie is also acknowledged. ELP and EJG are Research Career Members of CONICET. Part of this paper was presented as a poster at the " $9^{\circ}$ ENAPAVE (Encontro Nacional de Patologia Veterinária - Colégio Brasileiro de Patologia Animal)", Belo Horizonte, Minas Gerais, Brazil, 26-30th July 1999.

\section{REFERENCES}

Allen E. 1922. The oestrus cycle in the mouse. Am. J. Anat. 30:297-320.

Burguess D.E. \& Knoblock, K.F. 1989. Identification of Tritrichomonas foetus in sections of bovine placental tissue with monoclonal antibodies. J. Parasitol. 75:977-980.

Campero C.M., Ladds P.H., Hirst G.R. \& Vaughan J.A. 1989. Detection of Tritrichomonas foetus antigens in formalin-fixed, paraffin-embedded sections by the peroxidase-antiperoxidase technique. Aust. Vet. J. 66:264-266.

Diamond L.S. 1987. Lumen-dwelling protozoa: Entamoeba, Trichimonads and Giardia, p. 89-98. In: Jensen J.B. (ed.) In vitro Cultivation of Protozoan Parasites. CRC Press, Boca Raton, Florida, USA

Kulda J., Poislova M., Suchan P. \& Tachezy J. 1999. Iron enhancement of experimental infection of mice by Tritrichomonas foetus. Parasitol. Res. 85:692-699.

Hook R.R. Jr., St. Claire M.C., Riley L.K., Franklin C.L. \& Besch-Williford C.L. (1995). Tritrichomonas foetus: Comparison of isolate virulence in an estrogenized mouse model. Exper. Parasitol. 81:202-207.

Mutwiri G.K. \& Corbeil L.B. 1998. Genital and systemic immune responses in a murine model of Tritrichomonas foetus infection. Parasitol. 84:321-327.

Parsonson I.M., Clark B.L. \& Dufty J.H. 1976. Early pathogenesis and pathology of Tritrichomonas foetus infection in virgin heifers. J. Comp. Pathol. 86:59-66.

Portiansky E.L., Massone A.R. \& Gimeno E.J. 1997. Kinetics of epitope retrieval techniques for unmasking cytokeratins in bovine prostatic tissues after different formaldehyde fixation times. Appl. Immunohistochem. 5:194-201.

Rhyan J., Wilson K., Burgess D., Stackhouse L. \& Quinn W. 1995a. Immunohistochemical detection of Tritrichomonas foetus in formalin-fixed, paraffin-embedded sections of bovine placenta and fetal lung. J. Vet. Diagn. Invest. 7:98-101.

Rhyan J., Blanchard P., Kvasnicka W.G., Hall M. \& Hanks D. 1995b. Tissueinvasive Tritrichomonas foetus in four aborted bovine foetuses. J. Vet. Diagn. Invest. 7: 409-412.

Sanz M.E. \& Parma A.E. 1992. Desarrollo de un ensayo de dot-blot para la detección de adhesinas de Escherichia coli enterotoxigénica. Acta Bioquím. Clín. Latinoamer. 26:295-298.

Soto P., Monteavaro C.E., Echevarría H.E. \& Catena M.C. 1997. Evaluación de la patogenicidad de Tritrichomonas foetus. Revta Med. Vet., B. Aires, 78:146-149.

Soto P. \& Parma A. 1989. The immune response in cattle infected with Tritrichomonas foetus. Vet. Parasitol. 33:343-348.

St Claire M.C., Riley L.K., Franklin C.L., Besch-Williford C.L. \& Hook R.R. Jr 1994. Experimentally induced intravaginal Tritrichomonas foetus infection in the estrogenized mouse. Lab. Anim. Sci. 44:430-435.

Van Andel R.A., Franklin C.L., St Claire M.C., Riley L.K., Besch-Williford C.L. \& Hook R.R. Jr 1996. Lesions of experimental genital Tritrichomonas foetus infections in estrogenized BALB/c mice. Vet. Pathol. 33: 407-411. 